\title{
Impacts of Monetary Policy on Inflation in Bangladesh
}

\author{
Mohammad Nayeem Abdullah ${ }^{1}$, Kamruddin Parvez ${ }^{2}$, \& Rahat Bari Tooheen ${ }^{3}$ \\ ${ }^{1 \& 2}$ Lecturer, School of Business, Independent University, Bangladesh (IUB) Chittagong, Bangladesh \\ ${ }^{3}$ Lecturer, School of Environmental Science and Management, Independent University, Bangladesh \\ (IUB) Chittagong, Bangladesh
}

\begin{abstract}
The objective of this paper is to analyze and discuss the impacts of monetary policy on Bangladesh inflation, identify the major drawbacks of the policies in minimizing the inflation rate and suggest policy recommendations on some key issues of Bangladesh inflation. To estimate the effects of the monetary policy in Bangladesh, at first the impact of different monetary policy tools used by the "Central Banks" of the developed countries have been reviewed. Next, the impact of the monetary policy of Bangladesh Bank and government have been analyzed for which the data on money supply, growth of the GDP, changes in the price level, and changes in the unemployment rate have been quantitatively analyzed. We mainly used Consumer Price Index to determine the level on inflation in Bangladesh. Moreover, our study focuses on data collected from the 1950-2012, mainly focusing our study from the period of 2000-2012 as major transitions have been observed in the economy during the 12 years. We have further analyzed whether there is any correlation between (i) inflation rates and money supply, and (ii) inflation rates and growth of GDP. On the basis of the outcome of the qualitative and quantitative analysis, in the end findings and conclusion have been drawn. We have found the correlation, the impacts of monetary policy and inflation, their drawbacks and possible solutions such as independence of the monetary policy from the fiscal policy and enhancing the transparency, communication and signaling effect of policy moves, keeping the broad money in line with the estimated real GDP growth, borrowing from non-bank sources, and control money supply through various open market operations. Due to lack of access to sufficient data, some of our work is based on hypothesis and models. So some data vary according to the model being used. Lastly, even though, many works have been done from the perspective of developed and other developing countries, much work has not been carried out to establish the relationship between monetary policy and inflation in Bangladesh.
\end{abstract}

Keywords: Monetary Policy, Inflation, Bangladesh

GEL Classification Code: E31; E42; E50 


\section{INTRODUCTION}

Monetary policy in Bangladesh is equally important as in developed countries. Monetary policy basically targets price stability. For any government, one of the most urgent economic issues is to stabilize the price and maintain a price level within the limits of purchasing power of the common people. The notion that monetary policy should affect inflation dynamics is an old one, dating at least to Friedman's dictum that inflation is always a monetary phenomenon (1970). In his famous "Critique," Lucas (1975) showed how changes in monetary policy could, in principle, affect inflation dynamics. However, Lucas considered only very stylized monetary policies. There are several ways in which monetary policy may have changed over time. Ball, Mankiw, and Romer (1988) have argued that changes in monetary policy may lead to changes in the frequency of price adjustment. The New Open Economy Macroeconomics (NOEM) literature, pioneered by Obstfeld and Rogoff (1995), suggests that monetary policy affects the real economy through the interest rate and exchange rate channels. In a recent paper Maroney, Hassan, Basher, and Isik (2004) found that monetary policy plays a more important role than fiscal policy in enhancing the economic growth of Bangladesh. Bhuiyan (2012) found that a central bank that is transparent about inflation rate wants to maintain inflation and takes policy measures to lower inflation expectations. Yet, high inflation is a long-standing problem in Bangladesh. The historical record of conducting monetary policy in Bangladesh economy shows that the Central Bank has switched its operating targets many times. "The central bank can best contribute to high growth and financial stability by providing a stable macroeconomic environment through price stability" (Prasad 2010).

Monetary policy is concerned with the measures taken to control the supply of money, the cost and availability of credit. Like many developing countries, the primary focus of monetary policies in Bangladesh is to obtain high sustainable growth. However, to achieve and maintain a higher growth rate, policy makers need to understand the determinants of growth as well as how policies affect growth. In a developing country like ours the monetary policy has been effectively used as a tool for overcoming depression and inflation. Along with economic growth monetary policy also has to ensure price stability, as excessive inflation has an adverse distribution effect and hinders economic development.

Inflation is one of the most important macroeconomic variables in any economy for determining the monetary and fiscal policies of the government. It is measured by CPI. Using the data from January 2007 to October 2011, we observed that inflation movement in Bangladesh has been cyclic. There are many opinions regarding the proper reasons for inflation. Some researchers think that agricultural bottlenecks and successive balance of payment deficits are responsible for inflation. Another group thinks that expansionary monetary policy is the main cause of inflation in Bangladesh. Whatever the reasons for inflation and its impact on the economy of Bangladesh, this paper tries to determine the impacts of monetary policy on inflation.

In this paper, at first we discuss about some of the past studies that have been conducted on monetary policy and inflation in section 2. The remainder of the paper is organized as follows: section 3 provides the objectives of this paper, and section 4 provides the data sources and methodology used in our study. In section 5 we have presented the findings of each objective and lastly, in section 6, we draw the conclusions of our study.

\section{LITERATURE REVIEW}

There are several theories and empirical studies have been conducted on monetary policy globally over the past decades. Money supply and its prudent management and control 
through the monetary policy pursued by the central bank of a country can play a significant role in the managing and controlling of inflation in that country. The relationship between inflation and monetary policy remains controversial in both theory and empirical findings. Several earlier works on monetary policy failed to establish any meaningful relationship between inflation and monetary policy.

The monetarist approach, that money supply growth causes inflation, can be tested by observing the correlation between the rate of inflation and the rate of monetary growth. Causality can be determined by statistical analysis and institutional evidence. The direction of causality can be detected by examining the timing of the relationship between changes in monetary growth and changes in inflation. Monetarists Cagan (1956) and Friedman (1956, 1975) explained money supply as one of the major causes of inflation. The economists began to believe that increasing the monetary supply at a low but constant rate is the best way of maintaining low inflation and growth of the economy. Sunkel (1960) said that from a structuralist viewpoint, budget deficits and consequent expansion in money supply are not autonomous while the necessity of the essential commodities in the domestic market goes up, import is a must. As a result, rising imports and devaluation generate domestic inflation, price level spirals and borrowing through central bank increases the money supply causing a further rise in the price level. But tight monetary policy in this regard may cause scarcity in the domestic need of essential commodities. So, the some degree of control of monetary authorities is desirable. Friedman (1968) studied the role of monetary policy in the U.S economy and suggested that by setting a steady course, that course one of steady but moderate growth in the quantity of money, the monetary authority could make a major contribution to promoting economic stability with avoidance of either inflation or deflation of prices. It was found that in the developed nation's money supply changes precede price changes, which precede real production changes, lending support to the view that money supply changes are more likely to lead to inflation in this subsample (Cagan 1956; Deaver 1970; and Vogel 1974). He also mentioned that price changes are likely to be followed by money supply changes in less-developed economies. Another interesting finding was that generally the relationship between money supply changes and real production changes is positive for less advanced economies, but negative or negligible for the advanced. This later finding is suggestive that mild inflation may induce real economic growth.

The evidence on developing countries supports the argument that governments should not depend on expansionary monetary developments to induce growth. They will be retarding growth while at the same time reducing the welfare of the public by the deterioration of real balances by the induced inflation. Evidence on the inflationary impact of deficits through their impact on money supply growth include those by, for example, Aghevli and Khan (1978) in the case of Columbia, Indonesia, Dominican Republic, Brazil and Thailand. Rwegasira (1974), in a study which linked deficits with rising prices, concluded that government expansionary finance which characterized the economy from 1963-72, had been one of the sources of rising prices. He pointed that other important sources, like inelasticity in agriculture and falling import capacity, joined deficit financing in causing upward pressure on the general price level. A combination of declining productivity, declining production and inefficiency accompanied by excessive money supply in the economy seems to be important in the process of inflation according to Malima (1980), implying that an increase in the rate of growth of output and a reduction in the rate of money supply growth could be a solution to inflation.

Mckinnon, White and Davidson's (1983) non nested test of model selection suggested that real permanent income and the expected rate of inflation have been found to be important variables, both theoretically and statistically, in the money supply function. But this study does 
not show any direct relation of monetary policy with inflation. Gordon (1984) suggests that if the monetary authority tries to implement a rule to stabilize the interest rates by changing the money supply through open market operations, then the monetary base becomes endogenous to the determinants of the money demand functions. A dual relationship may therefore exist between the monetary base and the arguments of money demand functions. Chowdhury and Ahmed (1986) and Chowdhury, Dao, (1995) constructed a recursive VAR model to estimate the dynamic effects of monetary policy shocks on key macroeconomic variables of Bangladesh. However, since the recursive VAR approach is unable to capture simultaneous interactions among the monetary policy variable and other variables in the model, the recursive model identified erroneous policy shocks and hence generate misleading responses of macroeconomic variables. In Bangladesh, the interest rate is not the major target variable of the monetary authority. Interest rates are institutionally determined and in many cases are not responsive to money market conditions. Changes in the money supply in Bangladesh mainly originate from changes in reserve money (Hossain, 1988).

Maroney, Hassan, Basher, and Isik (2004) found that within the context of Bangladesh, monetary policy is more important than fiscal policy. As significant amounts of development expenditures for Bangladesh comes from foreign aid and grants, it is also argued that this aid must be channeled to productive activities so that it contributes to economic growth. Mansur (2007) argued in their paper that a well-defined and stable money demand function is a necessary condition for monetary policy to have predictable effect on the macroeconomic variables. Their paper applied the advanced technique of co-integration to estimate the demand for money balances in the case of Bangladesh and evaluates stability of the equations. The analysis shows that there exist a long-run relationship between real money, real income, inflation, and interest rate that remains stable over time. The long-run properties emphasize that both inflation and interest rate have negative effects on real money demand whereas real income has positive effects. Roberts (2006) considered the effects of changes in U.S policy on expectations formation, holding fixed the other behavioral relationships in the economy and argued that changes in policy can affect the reduced-form relationship between inflation and economic activity by reducing the signal content of economic slack for future inflation. The results suggest that changes in monetary policy can account for most or all of the change in the inflation level. Subrata, Ghatak, Willy Spanjers, (2007) discussed the potential benefits of monetary policy rules for transition economies (TEs). It is argued that the nominal interest rate may fail to be the appropriate instrument in such rules. One reason is the amount of non-calculable political and economic risk inherent in TEs. These risks lead to a significant and volatile-ambiguity premium in the interest rate over and above the normal risk premium, which makes the real equilibrium interest rate difficult to measure. Ambiguity of the public regarding the monetary policy leads to an ambiguity premium on inflation. Reserve Bank of India's (RBI) monetary policy strategy is still guided by the multiple objectives of price stability, growth and financial stability, with relative weights depending upon evolving domestic and global macroeconomic and financial conditions. Cavoli, Ramkishen, and Rajan (2008) conducted a study on India's monetary policy actions in a broader context by discussing whether the Reserve Bank of India (RBI) should shift from its current policy of heavily managed exchange rates to one involving greater currency flexibility, through analytical, empirical and policy dimensions. The recent history of exchange rate centered policy in India was studied. There were some evidence to suggest that the monetary policy rule tends to react to current inflation, but there is no evidence that it reacts to forecasts of inflation. Additionally, interest rates do not react at all to the exchange rate. Bhuiyan (2009) said that monetary policy is a key tool to influence the economic growth of a country. Therefore, it is important to understand the channel through 
which a monetary policy action influences the real economy as well as the time it takes for the policy action to affect economic activity. Recent Monetary Policy Statement of Bangladesh Bank (July 2009) by Bhattacharya and Khan said that traditional fiscal policy solutions were useful in confronting unemployment by increasing spending and cutting taxes, counter-acting inflation entailed reducing spending or raising taxes. The growing importance of monetary policy in economic stabilization efforts may reflect both political and economic realities. Monetary and fiscal policies differ in the speed with which each takes effect as the time lags are variable. Monetary policy is flexible and emergency rate changes can be made.

Gupta and Kabundi (2010) seek to assess the impact of monetary policy on house price inflation for the nine census divisions of the US economy. The results of this investigation show that house price inflation responds negatively to a positive monetary policy shock, suggesting that the framework does not experience the widely observed price puzzle encountered while analyzing monetary policy shocks with standard sized VARs but the responses are heterogeneous across the census divisions. Ali and Islam, (2010) estimated empirically the money supply function for Bangladesh and then examined how supply of money can be managed better to improve the economy of Bangladesh. They concluded that understanding the money supply process is critical for a better management of the monetary sector of the country including the management of interest rate and credit flows, and in controlling inflation, unemployment, and economic growth. Islam (2010) suggests that, the behaviour of money supply and its determinant (Money Multiplier) have a greater impact on monetary policy. Basically, behavior of the determinants shows that net foreign assets, net domestic assets, interest rate spread, government borrowing have a greater impact on money supply process in Bangladesh. It is to be accentuated that net foreign assets and net government borrowing have a greater impact in changing reserve money which in turn has an effect on inflation. Cristadoro \& Veronese, (2011) documented the unwinding of inflation expectations in India. The evidence gathered led to the conclusion that both the monetary policy strategy and framework of the Reserve Bank of India would benefit from further evolution in the direction of a precisely defined and overarching objective (price stability) and suggest that embracing a flexible inflation targeting approach is a possible solution. Antonio's, (2012) study shows a link between money growth and inflation in the euro area over a period of forty years by using the wavelets analysis and the study also suggests that the link presents both frequency and time-varying features. Reschreiter and Andreas (2011) suggest through empirical analysis that a constant mean of the real interest rate that shifts with the monetary policy regime change to inflation targeting. The mean-reverting level of the real interest rate has with the change in monetary policy to inflation targeting in U.K. Biswas, Winckler and Paul (2011) said that monetary policy influences the price level, growth of the economy, and employment generation. To estimate the effects of the monetary policy in Bangladesh, at first the functions and influences of different monetary policy tools used by the "central banks" of the developed countries were reviewed. Next, the impact of the monetary policy of Bangladesh Bank and government was analyzed at which the data on money supply, growth of the GDP, change in the price level, and change in the unemployment rate was quantitatively analyzed. Bhuiyan (2012) developed and found that the liquidity effect and the exchange-rate effect of the monetary policy shock are realized immediately, while industrial production responds with a lag of over half a year, and the inflation rate responds with a lag of more than one year.

Although many studies have been carried out to establish the relationship between monetary policy and inflation, very few studies have been conducted for Bangladesh. 


\section{ObJectives}

The objective of this paper is to analyze and discuss the impacts of monetary policy on Bangladesh inflation, identify the major drawbacks of the policies in minimizing the inflation rate and suggest policy recommendations on some key issues of the Bangladesh inflation, identify major challenges and suggest policy recommendations

The Objectives of the study are listed below:

- Discussion on the correlation between monetary policy and inflation

- Fluctuation of inflation rates over time in Bangladesh and its present condition due to monetary policies

- Impacts of monetary policy on inflation and the consequences

- To determine appropriate policies to control inflation rates in Bangladesh

\section{Methodology}

Our study is mainly based on secondary information. We have used the secondary data collected mainly from journals, books, previous studies and websites to analyze the past and prevailing monetary policies and inflation patterns in Bangladesh and also considered cross-country analysis. The study is made based on the analysis of secondary data obtained from the Bangladesh Bank and Bangladesh Bureau of Statistics (BBS). During the analysis, publications of Bangladesh Bank, its different issues of Monetary Policy Statements (MPS), Monthly Economic Trend, Bangladesh Bank website, etc were consulted. Tables as well as graphical presentation of relevant data were used to show its trends and outcomes in this study. Basically this study was confined to the behavior and trend analysis among the components of money supply. Suitable data have been extracted, organized, analyzed, illustrated and interpreted in the report with proper reasoning, analytical judgment, clarification and explanation.

\section{Measures of inflation:}

In Bangladesh, inflation is generally measured using CPI which measures consumer prices, and the GDP deflator, which measures inflation in the whole of the domestic economy. The prevailing view in mainstream economics is that inflation is caused by the interaction of the supply of money with output and interest rates. The inflation rate is the percentage rate of change of a price index over time. For instance, in January 2010, the Bangladesh Consumer Price Index was 324.21, and in January 2011 it was 350.54. The formula for calculating the annual percentage rate inflation in the CPI over the course of 2010 is:

$(350.54-324.21) / 324.21=0.103$ or $10.3 \%$.

The resulting inflation rate for the CPI in this one year period is $10.3 \%$, meaning the general level of prices for typical Bangladeshi consumers rose by $10.3 \%$ in 2010 .

Table: General, Food \& Non-food Inflation Rate in Bangladesh during FY 2001 to FY2011

\begin{tabular}{|c|c|c|c|c|c|}
\hline \multirow{2}{*}{\multicolumn{2}{|c|}{$\begin{array}{l}\text { Year } \\
\text { Point to Point }\end{array}$}} & \multirow{3}{*}{$\begin{array}{l}\text { General (\%) } \\
\text { Monthly Moving } \\
\text { Average } \\
1.94\end{array}$} & \multirow{3}{*}{$\begin{array}{l}\text { Food (\%) } \\
\text { Monthly } \\
\text { Average } \\
139\end{array}$} & \multirow{3}{*}{ Moving } & \multirow{3}{*}{$\begin{array}{l}\text { Non-food (\%) } \\
\text { Monthly Moving } \\
\text { Average } \\
3.04\end{array}$} \\
\hline & & & & & \\
\hline 2000 & - & & & & \\
\hline 2001 & - & 2.79 & 1.63 & & 4.61 \\
\hline 2002 & 3.58 & 2.79 & 1.63 & & 4.61 \\
\hline 2003 & 5.03 & 4.38 & 3.46 & & 5.66 \\
\hline 2004 & 5.64 & 5.83 & 6.92 & & 4.37 \\
\hline 2005 & 7.35 & 6.48 & 7.91 & & 4.33 \\
\hline 2006 & 7.54 & 7.16 & 7.76 & & 6.40 \\
\hline
\end{tabular}




\begin{tabular}{|l|l|l|l|l|}
\hline $\mathbf{2 0 0 7}$ & 9.20 & 7.20 & 8.11 & 5.90 \\
\hline $\mathbf{2 0 0 8}$ & 10.16 & 10.06 & 11.43 & 7.35 \\
\hline $\mathbf{2 0 0 9}$ & 4.60 & 5.51 & 7.9 & 4.2 \\
\hline $\mathbf{2 0 1 0}$ & 7.61 & 7.52 & 9.9 & 3.9 \\
\hline $\mathbf{2 0 1 1}$ & 11.97 & 9.76 & 13.90 & 4.32 \\
\hline
\end{tabular}

Source: Bangladesh Bureau of Statistics

\begin{tabular}{|l|l|l|l|}
\hline $\begin{array}{l}\text { Rate of Inflation } \\
\text { (as measured by CPI, base } \\
\text { 1995-96) }\end{array}$ & October, 2012 & September, 2012 & $\begin{array}{l}\text { October, } \\
2011\end{array}$ \\
\hline $\begin{array}{l}\text { Point to point } \\
\text { Monthly Average (Twelve } \\
\text { Month) }\end{array}$ & $7.22 \%$ & $7.39 \%$ & $11.42 \%$ \\
\hline
\end{tabular}

Source: BBS (Bangladesh Bureau of Statistics)

\subsection{FINDINGS OF OBJECTIVE 1}

\section{Correlation between monetary policy and inflation:}

Traditionally, it is believed that inflation is ultimately a monetary phenomenon, i.e., sustained inflation is the outcome of excessive money supply. Although it is the general wisdom that monetary policy tools are of immediate influence in controlling inflation. However, contemporary evidence amply illustrates that monetary policy cannot deal well with the inflationary impacts of external shocks such as the recent international price of oil \& related energy products. Many central banks as a consequence focus on the core inflation which is typically constructed by subtracting the most volatile components (e.g. food \& energy prices, indirect taxes, etc.) from the consumer price index (CPI). As a policy goal, core inflation may be a more credible target then CPI inflation. Then monetary policy surely requires independence. Various studies show that a higher degree of monetary-policy independence is associated with a lower inflation across the globe.

A significant body of literature has argued that general price level determination is essentially a fiscal, rather than a monetary, phenomenon (Cochrane, 1999). In the new view, an independent central bank is not sufficient to ensure price stability. Price stability requires not only an appropriate monetary policy, but also an appropriate fiscal policy. However, some economists think that today the primary tool for controlling inflation is monetary policy. A low positive inflation is usually targeted, as deflationary conditions are seen as dangerous for the health of the economy.

According to the famous monetarist economist Milton Friedman, "Inflation is always and everywhere a monetary phenomenon". Money supply plays a large role in inflation. Money supply growth in line with economic growth will result in stable prices; money supply growth above economic growth will lead to increases in prices. An increase in money supply involves increasing the amount of money in circulation. This can come about by the central bank decreasing interest rates or by increasing the amount of credit commercial banks can offer. Either way, people are encouraged to borrow more and have more money to spend. When consumer spending increases, there is a greater demand for goods/services than there is supply, and therefore prices rise. If the Central Bank does not control the money 
supply adequately, it may actually grow at a rate faster than that of the potential output in the economy, or real GDP. The belief is that this will drive up prices and hence, inflation.

Following the pioneering work by Obstfeld and Rogoff (1995), a number of open-economy monetary transmission models, such as those by Chari, Kehoe, and McGrattan (2002) and Galı and Monacelli (2004), made contributions to the NOEM literature. These models imply that monetary policy affects the real economy through the interest rate and exchange rate channels. For example, following a contractionary monetary policy shock, the interest rate rises. This causes an inflow of capital into the country from around the world, leading to an appreciation of domestic currency. The appreciation of domestic currency increases prices of home products relative to foreign ones, leading to a decline in net exports. The rise in the interest rate also increases the cost of borrowing and thus tends to dampen the demand for interest-sensitive consumption and investment expenditures. Therefore, the contractionary policy shock leads to a reduction in aggregate demand. Over short periods of time, since output is determined by aggregate demand, the fall in aggregate demand causes a fall in aggregate output. With a given underlying growth rate of potential output, the reduction in actual output implies a negative output gap. While this negative output gap might continue for a while, eventually the economic slack leads to a fall in wages and prices of other inputs. Finally, this reduction in firms' costs of production leads to a reduction in the price of output, that is, to a low inflation rate in the economy. Therefore, theoretically, while the effects of the policy shock on interest rates and exchange rates are realized immediately, this effect on the level of output is realized with a lag, and on the price level with further a lag.

For example, Bhuiyan and Lucas (2007), employing a recursive VAR model, found an appreciation of the home currency due to a contractionary monetary policy shock is inconsistent with what we expect from a contractionary monetary policy shock. They reported a decline in inflation for few quarters after an initial increase. The decline in inflation resulting from an expansionary policy shock is known as the price puzzle in the literature. Furthermore, a depreciation of exchange rate translates into a rise in the cost of imported commodities by making foreign goods more expensive, and thus induces an increase in the domestic price level. There is a close association between exchange rate fluctuations and inflation.

According to the studies by Fischer $(1983,1993)$, and Bruno and Easterly (1998), inflation has a negative effect on economic growth, thus monetary policy should aim at achieving a low level of inflation. This relationship is based on the actions of the Central Bank, which typically responds to increases in inflation by raising the interest rate and to decreases in inflation by lowering interest rates. Low interest rates correspond with a high level of money supply and allow for more investment in big business and new ideas which eventually leads to unsustainable levels of inflation as cheap money is available. The credit crisis of 2007 is a very good example here. If inflation is rising, then the Central Bank considers the demand for goods and services to be too high, so it tries to slow down spending by raising real interest rates. Conversely, if inflation is falling, then the Central Bank considers the demand for goods and services to be too low, so it tries to encourage more spending by lowering real interest.

Central banks routinely state monetary policies in terms of interest rates. For example, in October 2001, the European Central Bank stated that it had not changed interest rates recently because it considered current rates "consistent with the maintenance of price stability over the medium term" (ECB 2001, p. 5). In May 2001, Brazil's central bank increased interest rates because it was worried about mounting inflationary pressure. Another view, which follows from the Fisher equation, is that money and interest rates are positively related: increasing interest rates requires an increase in the rate on money growth. The Fisher equation states that the nominal interest rate equals the real interest rate plus the expected rate of inflation. If monetary policy does not affect the real interest rate (and errors 
in inflation expectations are ignored), then the Fisher equation implies that higher nominal interest rates are associated with higher rates of inflation. Since in the long run high inflation rates are associated with high money growth rates, the Fisher equation suggests that an increase in interest rates requires an increase in the money growth rate.

Wages and prices will begin to rise at faster rates if monetary policy stimulates aggregate demand enough to push labor and capital markets beyond their long-run capacities. In fact, a monetary policy that persistently attempts to keep short-term real rates low will lead eventually to higher inflation and higher nominal interest rates, with no permanent increases in the growth of output or decreases in unemployment. In the long run, output and employment cannot be set by monetary policy. In other words, while there is a trade-off between higher inflation and lower unemployment in the short run, the trade-off disappears in the long run. Policy also affects inflation directly through people's expectations about future inflation. For example, suppose the Central Bank eases monetary policy. If consumers and business people figure that it will mean higher inflation in the future, they'll ask for bigger increases in wages and prices. That itself will raise inflation without big changes in employment and output.

Bhuiyan (2012) found that a central bank that is transparent about the inflation rate it wants to maintain and takes policy measures to lower inflation expectations, becomes successful in controlling inflation. Central Banks in developing countries can also attempt to control inflation by measuring inflationary expectations and taking policy actions to lower these expectations. In addition, inflationary expectations can also be used as inputs to the monetary policy function in order to correctly identify exogenous policy shocks, which in turn can be used to estimate more precise impulse responses of macroeconomic variables. However, to my knowledge, most central banks in developing countries do not employ any economic model to estimate expected inflation nor do they have any explicit information about future inflation, except the forecast of inflation made by professional forecasters. Although Bangladesh Bank mentions that it conducts monetary policy by targeting money supply in order to influence the CPI inflation, the Bank is yet to develop any methodology to forecast future inflation.

Since a key objective of Bangladesh Bank is to control inflation, and the Bank can influence inflation only with a lag, it is important for an econometrician to use inflationary expectations as inputs to the monetary policy reaction function in order to correctly identify exogenous monetary policy shocks.

\subsection{FINDINGS OF OBJECTIVE 2}

\section{Fluctuation of Inflation Rates over Time in Bangladesh and Its Present Condition due to monetary policies}

Historical records have shown that inflation have increase over the time with the change in monetary policy. Using the data from January 2007 to October 2011, we can say that inflation movement in Bangladesh has been cyclic. There was a sharp increase, which almost reached double-digit level during October-November 2007. After that it had been relatively stable throughout the year 2008. But after that there was a sharp decline from end of 2008 through January 2009. Again in January 2009, it increased sharply but did not touch the double-digit level. In 2011, it again reached the double digital level. The inflation rate in Bangladesh was recorded at 7.39 percent in September of 2012. Historically, from 2001 until 2012, Bangladesh Inflation Rate averaged 8.26 Percent reaching an all time high of 11.97 Percent in September of 2011 and a record low of 1.66 Percent in June of 2001. 


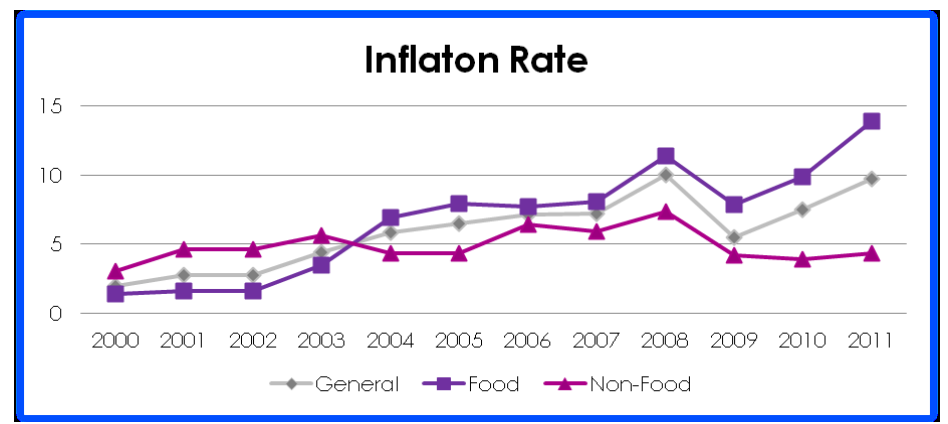

Figure: Trend of Inflation (general, food, non-food) in Bangladesh Source: Bangladesh Bureau of Statistics

Inflation as measured by the annual growth rate of the GDP implicit deflator shows the rate of price change in the economy as a whole. The GDP implicit deflator is the ratio of GDP in current local currency to GDP in constant local currency. Bangladesh is considered as a developing economy which has recorded GDP growth above 5\% during the last few years.

The inflationary situation in Bangladesh is on the rising trend, especially since August 2009, primarily owing to the increase in food prices. The food price hike has accelerated the general inflation rate in the country. Food inflation leaves a harmful impact on the purchasing power when the per capita GDP does not correspond with inflation. From August 2009 to June2010, the food inflation has risen by 5.7 percent whereas GDP growth rate has fallen by 0.1 percent, indicating that the purchasing power of the people shrunk drastically. Food inflation is higher in rural areas than in urban areas. Food inflation in rural areas reached near 11 percent, which is more difficult for the country side population to cope with. Rural food inflation increased to 10.51 percent in September'10, which was 9.95 percent in August, while urban food inflation in September declined to 7.95 percent against 8.95 percent in August

The Inflation; GDP deflator (annual \%) in Bangladesh was last reported at 6.33 in 2011, according to a World Bank report published in 2012. This page includes a historical data chart, news and forecasts for Inflation; GDP deflator (annual \%) in Bangladesh.

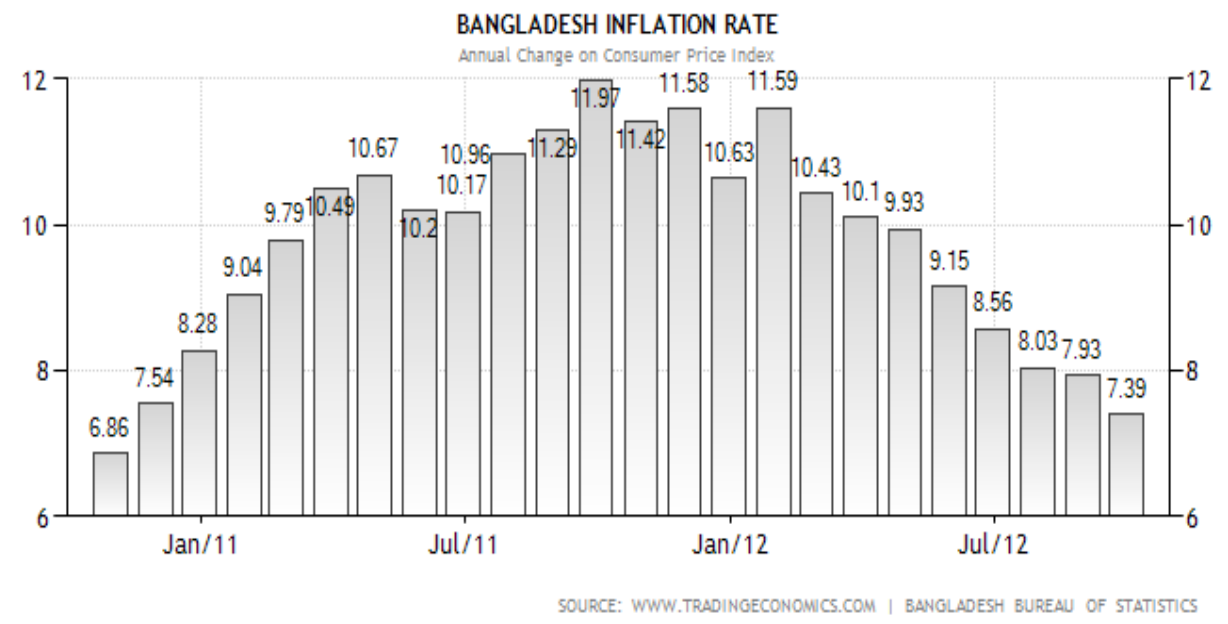




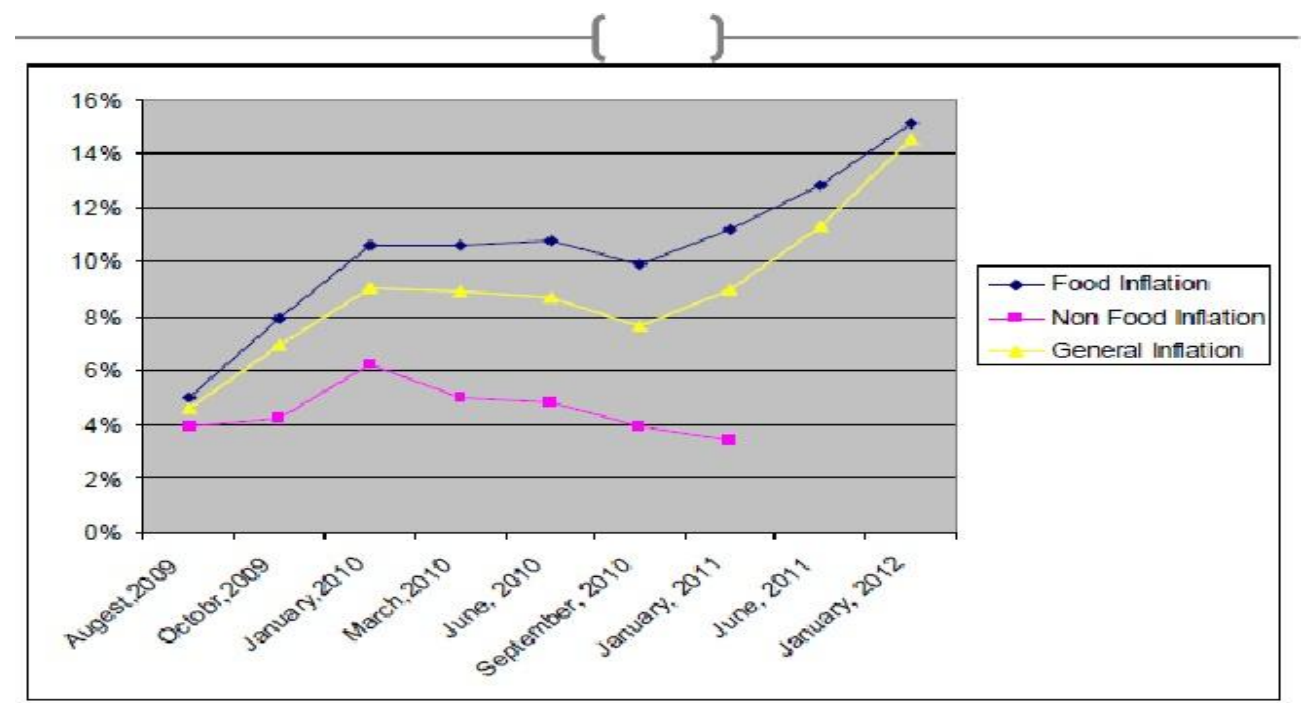

Source: Bangladesh Bureau of Statistics

In 1991 the lending rate was 14.99 which was high during 1992 but then it started to be reduced at 14.39 (1993) and 12.22 at 1995 . With the flexible use of the monetary instruments, broad money growth (Money Supply) was brought down from high rates of growth (14.1 percent) in the mid-1992to 10.6 per cent in June 1993 to reduce the rate of inflation. In the year 1995 government liberalized Credit to the private sectors in fiscal year1995 by reducing lending rates including those in the three selected sectors of agriculture, exports, and small and cottage Industries had to be restrained due to the rise in price levels. For this reason inflation rate has increased. Higher money supply growth and lower deposit rate in FY95 contributed to the comparatively higher inflation rates in 1995. In 1996 the lending rate was 13.41 which were accelerated to 14.16 in 1999. Supply shortages in the rural areas originating from political instability in FY96 and disruption due to floods in 1998 caused serious shortfall of food and also hampered all other agricultural production, which ultimately caused higher inflation rates in1996, 1998 \& 1999. Larger depreciation of the exchange rate has accelerated the inflation rate 2.79(2002) to 4.38 (2004). In 2001 the lending rate was 13.75 which were lowered to 10.93 in 2005 . Exchange rate might have played a significant role in causing inflation in 2005-2006 because of the introduction of flexible exchange rate regime since May 2003. A higher growth of money supply (13.84 at 2004 to 19.51 at 2006) added a lot to inflation in 2005-2006. In line with global trends, Bangladesh also experienced rising inflation with the 12-month average CPI inflation touching 9.94 percent in June 2008. In the fiscal year 2009 and 2010, global oil price shifted upward dramatically so fast that the price of fuel \& power has driven very sharp impact on our economy by increasing the price of Industrial product and reduces the output of industry. Though our government has taken needed initiatives to minimize the inflation rate but they have failed up to the expectation.

\subsection{FINDINGS OF OBJECTIVE 3}

\section{Impacts of monetary policy on inflation and the consequences:}

Monetary policy has positive and negative impacts on inflation. Middle class people are turning into lower middle class ones and the latter in turn joining the ranks of the poor. The poor are turning poorer from living costs outpacing earnings and buying powers of non-affluent sections 
of people decreasing dramatically from the lower purchasing power of the currency as such or the lowered value of their savings. We can say that inflation also directly lowers living standard. Because of inflation people enjoy same amount of product at higher price. An increase in the general level of prices implies a decrease in the purchasing power of the currency. That is, when the general level of prices rises, each monetary unit buys fewer goods and services.

The effect of inflation is not distributed evenly in the economy, and as a consequence there are hidden costs to some and benefits to others from this decrease in the purchasing power of money. Positive effects:

Labor-market adjustments: Nominal wages are slow to adjust downwards. This can lead to prolonged disequilibrium and high unemployment in the labor market. Since inflation would lower the real wage if nominal wages are kept constant, Keynesians argue that some inflation is good for the economy, as it would allow labor markets to reach equilibrium faster.

Instability with Deflation: Economist Tsaing noted that once substantial deflation is expected, two important effects will appear; both a result of money holding substituting for lending as a vehicle for saving. The first was that continually falling prices and the resulting incentive to hoard money will cause instability resulting from the likely increasing fear, while money hoards grow in value, that the value of those hoards are at risk, as people realize that a movement to trade those money hoards for real goods and assets will quickly drive those prices up. Any movement to spend those hoards once started would become a tremendous avalanche, which could rampage for along time before it would spend itself. Thus, a regime of long-term deflation is likely to be interrupted by periodic spikes of rapid inflation and consequential economic disruptions. Moderate and stable inflation would avoid such as swing of price movements.

Financial Market Inefficiency with Deflation: The second effect noted by Tsaing is that when savers have substituted money holding for lending on financial markets, the role of those markets in channeling savings into investment is undermined. With nominal interest rates driven to zero, or near zero, from the competition with a high return money asset, there would be no price mechanism in whatever is left of those markets. With financial markets effectively euthanized, the remaining goods and physical asset prices would move in perverse directions. For example, an increased desire to save could not push interest rates further down (and thereby stimulate investment) but would instead cause additional money hoarding, driving consumer prices further down and making investment in consumer goods production thereby less attractive. Moderate inflation, once its expectation is incorporated into nominal interest rates, would give those interest rates room to go both up and down in response to shifting investment opportunities, or savers' preferences, and thus allow financial markets to function in a more normal fashion.

\section{Negative effect:}

High or unpredictable inflation rates are regarded as harmful to an overall economy. They add inefficiencies in the market, and make it difficult for companies to budget or plan longterm. Inflation can act as a drag on productivity as companies are forced to shift resources away from products and services in order to focus on profit and losses from currency inflation. Uncertainty about the future purchasing power of money discourages investment and saving. And inflation can impose hidden tax increases, as inflated earnings push tax payers into higher income tax rates unless the tax brackets are indexed to inflation.

With high inflation, purchasing power is redistributed from those on fixed nominal incomes, such as some pensioners whose pensions are not indexed to the price level, towards those with variable incomes whose earnings may better keep pace with the inflation. This redistribution of purchasing power will also occur between international trading partners. Where fixed exchange rates are imposed, higher inflation in one economy than another will 
cause the first economy's exports to become more expensive and affect the balance of trade. There can also be negative impacts to trade from an increased instability in currency exchange prices caused by unpredictable inflation.

Hoarding: People buy durable and/or non-perishable commodities and other goods as stores of wealth, to avoid the losses expected from the declining purchasing power of money, creating shortages of the hoarded goods.

Allocation inefficiency: A change in the supply or demand for a good will normally cause its relative price to change, signaling to buyers and sellers that they should re-allocate resources in response to the new market conditions. But when prices are constantly changing due to inflation, price changes due to genuine relative price signals are difficult to distinguish from price changes due to general inflation, so agents are slow to respond to them. The result is a loss of allocation efficiency.

Menu change: With high inflation, firms must change their prices often in order to keep up with economy-wide changes. But often changing prices is itself a costly activity whether explicitly, as with the need to print new menus, or implicitly.

Business Cycle: Inflation sets off the business cycle. Some economists hold this to be the most damaging effect of inflation. Artificially low interest rates and the associated increase in the money supply lead to reckless, speculative borrowing, resulting in clusters of malinvestments, which eventually have to be liquidated as they become unsustainable.

Shoe leather: High inflation increases the opportunity cost of holding cash balances and can induce people to hold a greater portion of their assets in interest paying accounts. However, since cash is still needed in order to carry out transactions this means that more "trips to the bank" are necessary in order to make withdrawals, proverbially wearing out the "shoe leather" with each trip.

\subsection{FINDINGS OF OBJECTIVE 4}

\section{To Determine Appropriate Policies To Control Inflation Rates in Bangladesh}

There are a number of methods that have been suggested to control inflation. Central banks can affect inflation to a significant extent through setting interest rates and through other operations. High interest rates and slow growth of the money supply are the traditional ways through which central banks fight or prevent inflation, though they have different approaches. Monetarists emphasize keeping the growth rate of money steady, and using monetary policy to control inflation (increasing interest rates, slowing the rise in the money supply). Keynesians emphasize reducing aggregate demand during economic expansions and increasing demand during recessions to keep inflation stable. Control of aggregate demand can be achieved using both monetary policy and fiscal policy (increased taxation or reduced government spending to reduce demand)

It appears that the monetary system in Bangladesh has a built in bias towards expansion of money supply. It is commonly acknowledged that inflation is hard to prevent in a country in which the government has direct and indirect authority to print money to finance a fiscal deficit. Inflation is harder to prevent if the government creates money not only to finance fiscal deficit but also to provide subsidized credit to both the private and public sectors. Here we explain some strategic point that might be useful to reduce inflation.

We propose a number of policy recommendations for dealing with high inflation.

- Central bank can be entirely independent of government influence to achieve the rate of inflation that is deemed to be appropriate. Fiscal policy considerations cannot dictate monetary policy. Freedom from fiscal dominance implies that government borrowing from the central bank is low or nil, and that domestic financial markets have enough 
depth to absorb placements of public debt, such as treasury bills. If fiscal dominance exists, inflationary pressures of a fiscal origin will undermine the effectiveness of monetary policy by obliging the Central Bank to accommodate the demands of the government, say, by easing interest rates to achieve fiscal goals. The monetary authority in Bangladesh is not independent of the fiscal authority and that it merely implements the decisions regarding credit expansion and monetization of budget deficit taken by the executive branch of the government. An implication of this is that the ultimate responsibility for the expansionary monetary policy in Bangladesh lies with the Government (Bangladesh Economic Update, 2011).

- Enhancing the transparency, communication and signaling effect of policy moves.

- To contain inflationary pressure in the economy, the growth of broad money should be in line with the estimated real GDP growth and a target for the inflation rate.

- As the government borrowing from non-bank sources is mainly non-inflationary, the government may prefer to borrow more from non-bank sources (national savings schemes) by reinstalling/introducing some long-term savings schemes as were in force earlier.

- Measures may be taken to make the exchange rate responsive to that of neighboring countries especially India by shunning the interventionist exchanges rate policy of Bangladesh Bank.

- The growth of reserve money arising from reserve accumulation maybe offset by sterilization. Bangladesh Bank may sell government securities for which it will have to pay interest.

- The government should maintain sufficient buffer stock of food grain (rice and wheat) in order to meet any kind of shocks. This will instill confidence in people.

- The surveillance on the part of the government may be enhanced through weekly monitoring of domestic and international prices of essential commodities.

- To inject competition in the market, the government should promote small and medium traders along with big importers for import of essential commodities, and help them get credit from commercial banks.

- The government should promote the establishment of producers' cooperatives, which will work towards ensuring fair prices of their products, and at the same time help eliminate unnecessary agents in the supply chain. This will help stabilize the market price.

- More investment in the agriculture sector is needed to undertake research and extension work in order to invent/upgrade modern technology to boost agricultural production, strengthen capacity in storage, marketing and management along with setting up of agro-based industries.

- $\quad$ Like the Indian state trading agencies, the government should use the experience of Trading Corporation of Bangladesh (TCB) by strengthening its capacity with skilled manpower to break up any collusive oligopolistic power exercised by the private sector and thus improve the competitiveness of the distribution network.

- $\quad$ To strengthen local currency Government has to increase Remittance Inflow, Export \& Production.

- The policy makers have to keep a sharp eye on cost behavior in the relevant periods.

- Cutting down indirect tax on commodities may help to reduce inflation pressures temporarily.

\section{CONCLUSION}

The purpose of this study has been to discuss the relative impact of monetary policies on economic activities in Bangladesh. The growing importance of monetary policy and the 
diminishing role played by fiscal policy in economic stabilization efforts may reflect both political and economic realities of our country. Moreover, inflation acts as an important and key variable which influences other macro economic variables of a country. We have seen that, the central bank uses interest rates and the money supply and many other monetary tools to guide economic growth by controlling inflation and stabilizing currency. We have analyzed the consumer price index and several other indicators to understand the impact of monetary policy on inflation. We have found out that, the inflation rates are co-related with the growth rate of gross domestic product and money supply in Bangladesh. There is positive co-relation between the rate of inflation and rate of change in GDP at constant prices in Bangladesh. Furthermore, there is negative co-relation between rate of inflation and changes in money supply in Bangladesh. Bangladesh had favorable current account position for which it could keep its currency slightly stronger. However, it should adopt some contractionary policy because of rising current account deficit. We believe that, the monetary policy should be contractionary at times, even if it reduces economic growth of the country because in the long run, it may bring about stability to our economy. Moreover, we find a lag in the policy response of Bangladesh Bank to higher inflationary expectations. They don't have sufficient and reliable policies to cope with inflation and even if they do, they are not actively well-used. In today's environment of global finance, fixed exchange rates is often not a viable option for fighting inflation. Thus, governments must make important decisions about monetary policy.

\section{REFERENCES}

Aghevli and Khan. 1978, "Government Deficits and the Inflationary Process in Developing Countries", IMF, Staff Papers, Vol. 25, No. 3, pp. 146-162

Ahmed, S. 1977 "Demand for Money in Bangladesh: Some Preliminary Evidence”, Bangladesh Development Studies, vol-5, issue-2, pp. 264-286

Ali and Islam 2010,Money Supply Function for Bangladesh: An Empirical Analysis. AIUB Bus Econ Working Paper Series, No 2010-01

Andreas and Reschreiter, 2011 The effects of the monetary policy regime shift to inflation targeting on the real interest rate in the United Kingdom, Economic modelling. -Amsterdam [u.a.] : Elsevier, ISSN 0264-9993, ZDB-ID 868243. - Vol. 28, 1/2, pp. 754-759

Antonio, 2012, Money Growth and Inflation in the Euro Area: A Time-Frequency View. Oxford Bulletin of Economics and Statistics, Vol. 74, Issue 6, pp. 875-885, 2012

Ball and Mankiw et al, 1988. "The New Keynsesian Economics and the Output-Inflation Tradeoff," Brookings Papers on Economic Activity, Economic Studies Program, The Brookings Institution, vol. 19(1), pages 1-82.

Bangladesh Economic Update. (2011). Food Prices and Inflation Trajectory. Bangladesh Economic Update. Volume 2, No. 1, January-February 2011

Bhattacharya and Khan, 2009, Recent Monetary Policy Statement of Bangladesh Bank, An Analytical Commentary, Occasional Paper: 82, JEL codes: E52 F31 F33

Bhuiyan and Lucas et al, 2007, "Real and nominal effects of monetary policy shocks", Canadian Journal of Economics, 40, 2,pp. 679-702.

Bhuiyan, 2009, "Monetary transmission mechanism in a small open economy: a Bayesian structural VAR approach", Queens Economics Department Working Paper No.1183

Bhuiyan 2012, The Effects of Monetary Policy Shocks in Bangladesh: A Bayesian Structural VAR Approach In International Economic Journal, 26(02), pp. 301-316. 
Biswas, Winckler et al 2011: Approximation of the influence of Monetary Policy on economic growth, employment generation, and inflation- A case study in Bangladesh, IJRFM Volume 1, Issue 3 (July, 2011) (ISSN 2231-5985)

Bruno \& Easterly 1998, Inflation Crises and Long-run Growth. J. of Monetary Economics, 41: pages 3-26

Cagan 1956 "Monetary Dynamics of Hyperinflation", in M. Friedman, editor, Studies in the Quantity Theory of Money. Chicago: University of Chicago Press, pp. 47-68

Cavoli and Ramkishen, et al, 2008, Open economy inflation targeting arrangements and monetary policy rules: application to India, Indian growth and development review. - Bingley: Emerald, ISSN 1753-8254, ZDB-ID 24625097. - Vol. 1.2008, 2, pp. 237-251

Chowdhury and Abdur, 1986, “Vector auto regression as an alternative macro-modeling technique", Bangladesh Development Studies, 14, pp. 21-32.

Chowdhury and Dao 1995. "Monetary policy, output and inflation in Bangladesh: a dynamic analysis,"Applied Economics Letters, Taylor and Francis Journals, vol. 2(3), pages 51-55

Cochrane, 1999. "A Frictionless View of U.S. Inflation," NBER Chapters, in: NBER Macroeconomics Annual 1998, volume 13, pages 323-421 National Bureau of Economic Research, Inc.

Cristadoro and Veronese, 2011,"Monetary policy in India: is something amiss?", Indian Growth and Development Review, Vol. 4 Iss: 2 pp. $166-192$

Deaver, 1970, "The Chilean Inflation and the Demand for Money", in D.M. Meiselman (ed.), Varieties of Monetary Experience, Univ. of Chicago Press, Chicago, pp. 132-145

ECB 2001, A guide to Eurosystem staff macroeconomic projection exercises, June.

Fischer and Stanley 1983 Indexation and Inflation, Journal of Monetary Economics 12,pp. 519-541.

Fischer, S., 1993. The role of macroeconomic factors in growth. Journal of Monetary Economics 32 (3), pp. 485-511

Friedman, M., 1956. The quantity theory of money: a restatement. In: Friedman, M. (Ed.), Studies in the quantity theory of money (Chicago: University of Chicago Press), pp. 3-21.

Friedman 1961 "The Lag in the Effect of Monetary Policy", Journal of Political Economy, Vol. 69, p.447-66

Friedman, 1968, The Role of Monetary Policy, The American Economic Review, Vol. 58, No. 1, pp. 1-17.

Friedman, 1970. "A Theoretical Framework for Monetary Analysis, "NBER Books, National Bureau of Economic Research, Inc, pp.-313-344

Friedman 1971 "A Monetary Theory of National Income", Journal of Political Economy, Vol. 79, pp. 323-37.

Friedman, B.M., 1975. Targets, instruments, and indicators of monetary policy, Journal of Monetary Economics 1, pp. 443-473

Galí \& Monacelli, 2004. "Monetary policy and exchange rate volatility in a small open economy," Economics Working Papers 835, Department of Economics and Business, Universitat Pompeu Fabra, pages- 342-364

Ghatak and Spanjers, 2007 "Monetary policy rules in transition economies: the impact of ambiguity", International Journal of Development Issues, Vol.6 Iss:1, pp.26-37 Gordon, 1984, The Short Run Demand for Money: Reconsideration", Journal of Money. Credit, and Banking, Vol.16, No. 4, pp 234-246

GOB, Bangladesh Economic Review (Various Issues), Ministry of Finance, Government of Bangladesh

Gupta, and Kabundi, 2010: The effect of monetary policy on house price inflation: A factor augmented vector auto regression (FAVAR) approach, Journal of Economic Studies, Vol. 37 Iss: 6, pp.616 - 626

Hossain A. 1988 A quarterly short run money demand model for Bangladesh 1974: $1985: 4$, The Bangladesh Development Studies, 16, pp. $1-30$. 
Islam, 2010: Monetary Policy and Money Supply Process in Bangladesh: An Analytical Review, Institute of Governance Studies, BRAC University, Dhaka, Bangladesh, unpublished

Lucas, 1975. “Econometric Policy Evaluation: A Critique." Carnegie-Rochester Conference Series 1, pp.19-46.

Mackinnon, White, et al, 1983 Test for model specification in the presence of alternative hypothesis: some further results, Journal of Econometrics, 21, pp. $53-70$

Malima, K.A. 1980, "Inflation in the Tanzania Environment" in Rwegasira K.S .P and L.A. Kanneworff, (eds.) Inflation in Tanzania (Causes, Effects and Control). Institute of Finance Management (IFM), Dar-es-Salaam, pp. 123-142

Mansur 2007: Cointegration, Error Correction and the Demand for Money in Bangladesh, Bangladesh Institute of Development Studies (BIDS), ID code: 21026, unpublished

Maroney, \& Hasan, et al, 2004: A macro econometric model of Bangladesh economy and its policy implications, Journal of Developing Areas 38.1 pp. 135-149.

Ramon Moreno \& Agustin Villar, 2010. "Inflation expectations, persistence and monetary policy," BIS Papers chapters, in: Bank for International Settlements (ed.), Monetary policy and the measurement of inflation: prices, wages and expectations, volume 49, pages 77-92 Bank for International Settlements.

Obstfeld and Rogoff., 1995. "Exchange Rate Dynamics Redux," Center for International and Development Economics Research (CIDER) Working Papers C95-048, University of California at Berkeley

Prasad, 2010, "After the Fall", IMF, Finance and Development, (June): pp.22-25

Roberts, 2006. "Monetary Policy and Inflation Dynamics," MPRA Paper 812, University Library of Munich, Germany,143-165

Rwegasira, 1974. "Monetary Stability and Economic Development in Uchumi, Vol. 1 No. 2, pp. 114-135

Subrat,and Ghatak, et al, 2007: Monetary policy rules in transition economies: the impact of ambiguity, International Journal of Development Issues, Vol. 6 Iss: 1, pp. 26 - 37

Sunkel, 1960, Inflation in Chile: Unorthodôx approach. International Economic Papers, 10, 107-31

Tsaing, S.C. 1969, Journal of Money, Credit and Banking, I(1969), 266-80 "A Critical Note on the Optimum Supply of Money", (p272)

Vogel, R. 1974: "The dynamics of inflation in Latin America”. American Economics Review, pp. 102-14

Websites:

> http://www.bangladesh-bank.org/pub/monthly/selectedecooind/magecoind.pdf

> http://www.thedailystar.net/newDesign/news-details.php?nid=242341

$>\quad$ http://www.thedailystar.net/newDesign/news-details.php?nid=248571

$>\quad$ www.bb.org.bd 2.

$>\quad$ www.mof.gov.bd 3.

$>\quad$ www.economywatch.com 4

$>\quad$ www.bbs.gov.bd/home.aspx 